\title{
Does Accounting Choices Affect Financial Reporting Communication? Some Critical Consideration
}

\author{
Pina Puntillo, Valentina Cavaliere \\ University of Calabria, Cosenza, Italy
}

\begin{abstract}
The aim of this work is to analyze the critical issues related to stock options accounting granted to employees. Given the different ways to collect stock option plans, it follows that according to the accounting treatment adopted, it changes the financial reporting of stock option plans, and thus the information communicated to stakeholders and markets in general. The examination of the accounting treatment of stock options starts from the study of legal changes relating to the stock options and various criteria suggested will be presented for the evaluation of the options and for detection of their cost in the financial statements of companies (Guay, Kothari, \& Sloan, 2003). After the analysis of international accounting standards issued by the International Accounting Standards Board (IASB) on the subject, specifically the "IFRS 2", we can state that they had a strong impact on Italian companies (Ciampaglia, 2008). The central aspect of the study, however, consists of an analysis of the market effects of accounting for the cost associated with the issuance of stock option plans (Cerri \& Sottoriva, 2010). Budgeted costs relating to the adoption of stock option plans granted to employees change the measures of economic performance of the enterprise, such as return on investment (ROI) and return on equity (ROE), with significant effects on the evaluation of the economic capital of the company. A company that does not account for costs related to stock option plans recorded a best exercise, but it could distort the valuation of financial analysts (Tagliavini, 2000). Finally, it can be observed that the proper accounting of costs associated with stock options is a prerequisite for the comparability of financial statements of companies that grant, and it is therefore necessary to adequately reflect the value of the company.
\end{abstract}

Keywords: stock options, economic performance, financial reporting communication

\section{Stock Options: Context Analysis}

The stock options are call options on shares of the company, offered especially to executives and top management as a way of variable remuneration in the medium/long term, exercisable within a predetermined period of time and at a price (exercise) initially fixed (Onesti \& Romano, 2010). The institution of the stock options can be framed in the group of theories based on the separation between ownership and control within companies. Assuming that the interests of shareholders (principal) are different from those of the management (agent), with resulting problems and agency $\operatorname{costs}^{1}$, the stock option plans ${ }^{2}$ can be qualified as tools

Pina Puntillo, researcher, Department of Business Economics, University of Calabria. Email: pina.puntillo@unical.it.

Valentina Cavaliere, Ph.D. in Applied Economics and Managerial Decisions, Department of Business Economics, University of Calabria.

1 The agency relationship is defined by Jensen and Meckling (1976, p. 310) as "a contract under which one or more persons (the principal) requires another person (the agent) to hold on behalf of a given task, implying a delegation of power to the agent". "The divergence of interests originates in asymmetric information and opportunistic behavior implemented by the parties" (p. 324).

2 The analysis in this paper is limited to the fees paid to staff in the form of allocation of options ("stock options" or "equity compensation”), and does not consider other forms of compensation covered by IFRS 2 (stock plans grant, cash-settled plans, action plans designed to suppliers of goods, etc.). 
potentially oriented to resolve the problems of agency, creating a convergence of interests between management and ownership (Jensen \& Meckling, 1976). The stock option plans are aimed to corporate entities that can play different positions and roles; they generally consist of directors and members of senior management; sometimes, however, the assignment is extended to all company personnel (Corbella, 2004). The decision of remunerating its managers and employees with shares or stock options rather than cash, as well as to align the interests of managers with those of shareholders, creates employee loyalty, team group spirit, and sense of belonging.

The allocation of shares to managers activates a link between the remuneration of these executives and the performance of the company shares, pushing the top management to achieve the typical objectives of the asset (Filonzi, 1999). The spread of these tools is then supported by the benefits of both accounting and taxes related to their use. Achard and Castello (2000) also argued that the stock option plans are effective tools for long-term incentive as they direct the action of managers to create value by monetizing the realization of capital gains. A stock option plan will in fact be more effective as long as it can significantly affect the process of creating shareholder value (Zattoni, 2003, p. 87). The link between payment and performance introduced by stock options involves an additional cost component, which Cappiello (2003, p. 137) called "prize" requested by managers for the firm's risk tolerance. In order for this system of remuneration to be efficient, it is necessary that this cost, connected to the prize for the risk, is lower than the benefits associated with the introduction of the variable component. From a technical point of view, different categories of stock options are distinguished. However, to deepen the technical aspects of the stock option plan is not the objective of this work, which is instead aimed at deepening the relationship between the methods of stock options accounting and the proper financial business communication. As we will see later, according to the method used, there is a change in the budget values, in the period performance and then in the economic and financial indicators. Consequently, it changes the information given to the financial markets since the balance sheet is the main tool of economic and financial communications for firms. Stock options are suitable, in other words, to be instruments for implementing budgetary policies, thus affecting financial statement disclosure on the markets.

\section{Introduction of the Principle of Return on Equity (ROE) in the International Context}

The stock option plans have originated in the US, where they are regulated for the first time, due to the significant development of the movable market and the wide separation of ownership and firms controlling. Specifically, the first accounting regulatory concerning the phenomenon of stock option plans dates back to 1972, when the "Accounting Principles Board" (APB) gave off the APB Opinion No. 25, "Accounting for Stock Issued to Employees”, which introduced the principle that equity compensation plans should have led to the rise of costs charged to the results of the company concerned, measured by the intrinsic value of the options granted to employees. The accounting standard required that the budgeting of stock options was commensurate with the intrinsic value (intrinsic value method) ${ }^{4}$. Before Opinion No. 25, no provision provided for the recognition in the balance sheet of values associated with this type of operations.

\footnotetext{
3 The Accounting Principles Board (APB) is a body of the American Institute of Certified Public Accountants (AICPA), created in 1959 which operated, ruling on accounting standards until 1973, when it was replaced by the Financial Accounting Standards Board (FASB).

${ }^{4}$ The intrinsic value method was criticized by several authors, including Melis, Carta, and Gaia (2011), who said that this method considers only the intrinsic value and not the "time value" as well, i.e., the probability that at the time of the exercise of the option, the market price would be higher than that at the date of issue.
} 
The intrinsic value of the stock options is equal to the difference between the exercise price and the current value of the security underlying the option, and is positive only if the first is less than the second. Conversely, if the share price is at or below the exercise price, then option's intrinsic value is zero (Zattoni, 2001).

The intrinsic value method has some limitations generated by the fact that accounting the intrinsic value of the option in the financial statements does not allow estimating the "time value", i.e., the probability that at the time the option is exercised, the market price is higher than that at the issue date (Melis et al., 2011). Another theory points out how the cost to be shared should be an expression of the service provided by the employee and this is not adequately represented in the intrinsic value (Di Carlo, 2009). The reference to the intrinsic value of the options was justified by the fact that at the time of writing this paper, there were no standard options traded on regulated markets and the main models of option pricing had yet to be developed. According to APB Opinion No. 25, the value to be recognized among the negative income was essentially the difference between the predetermined price (strike price) when the option was exercised by the employee and the stock's market value at the date of issue of the option. This disparity was called "intrinsic value" ${ }^{5}$ The intrinsic value of the option is positive (and therefore represents a cost to the company issuing the stock options) until the amount that the option is exercised is less than the value of the shares on the market at the time of the right issue. Actually, the intrinsic value of an option can never be negative because if the exercise price is higher than the strike price, the holder will simply let the option expire without exercising it, not suffering then the loss arising from its exercise. ${ }^{6}$ According to the standard, the time of the recording had to coincide with the date on which both the number of shares to be allocated and the exercise price of the options were known. The APB Opinion No. 25 stipulated that the cost of the plans had to be recognized the time the options were issued (always according to the intrinsic value) operating then estimates on the exercise price and the number of shares that would have been received at the end of the plan. At the end of each financial year included in the service period of the plan, the intrinsic value of the options had to be re-estimated, by comparing the current market value of the shares with the exercise price of the options estimated at that date. Essentially, the firm at the end of each financial year had to estimate the intrinsic value of all options issued, determine the installment of the year and compare, in the following years, the amount of new shares with those calculated previously, possibly by charging an extraordinary part of income (positive or negative) to correct the estimates made. The accounting system established by the Opinion No. 25 not only allowed disguising the high salaries of executives, but also produced important reflections with reference to the disclosure in the financial statements. These issues led the FASB in 1984 to reconsider the matter through an "Invitation to Comment: Accounting for Compensation Plans Involving Certain Rights Granted to Employees "”, a request to stakeholders to report their positions on the topic.

After a decade of intense activity, in order to contribute to the true and fair view of the phenomenon in the budget, in June 1993, the FASB presented an "exposure draft", entitled "Accounting for Stock-Based Compensation", in which for the first had been recommended the inclusion of stock options in the income

\footnotetext{
${ }^{5}$ For an in-depth analysis about this, see the contribution of Barlev and Haddad (2003).

${ }^{6}$ In fact, "when the beneficiary acquires the issue right, the difference between the exercise price and the market value is for him a potential earning" (Melis et al., 2011, p. 22). Still, "if the stock price falls below the exercise price the beneficiary of the stock options loses the entire value of the incentive” (Zattoni, 2003, p. 87).

7 Referring see Dechow, Hutton, and Sloan (1996, p. 19).
} 
statement as negative income, accounted for using the fair value (rather than the intrinsic value). ${ }^{8}$ The FASB's decision was based on a logic consistent with the accounting theory: since the remuneration for employees is an operating cost for the company, if the stock option is a mode of payment for employees, as it represents half transfer of wealth in favor of its employees in exchange for their work, then the cost should be recognized in the income statement under negative income. It then reaffirmed the need to charge the staff for accounting duties in the issuance of stock options. The valuation at fair value, rather than the intrinsic value, can better represent the essence of the transaction. ${ }^{9}$ The reactions to the issue of the document were glowing and the exposure draft met strong opposition from large US companies, whose income on equal terms would have decreased significantly due to the higher costs accounted for (Freeman \& Larsen, 1997). The need to propose a solution generally accepted by all led, in 1995, to the adoption of the "Statement of Financial Accounting Standards" (SFAS) No. 123 which allowed the use of the method of evaluating the intrinsic value introduced by APB Opinion No. 25 as an alternative method to the imputation of the cost measured at fair value through profit or loss (Corbella \& Florio, 2010), with the only obligation to highlight the profit in the additional note, and incomes per share "pro-forma", that is, the net income that would have been determined if the cost had been recognized using the forecasts of statement No. 123, calculated taking into account the cost of the fair value of stock options (Bell, Landsman, Miller, \& Yeh, 2002). This alternative was accepted despite the clarification of the FASB that the most appropriate and therefore recommended measurement method was the remaining fair value, given its greater information capacity. The suggestion of the FASB had little follow-up by US companies. Almost all of the latter chose to adopt the alternative method, illustrating the effects of stock options in the additional notes rather than ascribing in the income statement the cost of the option at fair value (Apostolou \& Crumbley, 2001). Only in December 2004, SFAS No. 123 was significantly modified by the FASB with the elimination of the intrinsic value method introduced by APB Opinion No. $25 .^{10}$ In the new SFAS No. 123, the criteria of fair value became mandatory. The rationale for this choice is provided by the intention to conform to IFRS and to the more general objective of compliance with accounting policies. Through the "revised" accounting standard, the remuneration of employees through the issue of stock options was equivalent to other modes of compensation to employees and therefore its cost, assessed according to the criteria of fair value, is to be mandatorily enrolled in the income statement under negative components income. To be noted that the Board, in defining the concept of fair value applied to stock options, refers necessarily to the values expressed by the market. According to the FASB, prices that are formed on the regulated markets are, in fact, the best evidence of fair value and should be used as a basis of measurement. Not being available to date market prices with reference to stock options granted to employees, it is necessary to refer to specific models of option pricing. The FASB, in this respect, requires that the assessment should be conducted using mathematical models of Black and Scholes (1973).

\footnotetext{
${ }^{8}$ The US is the country where it is more widespread the use of stock options and where for the first time their financial reporting has been regulated. Initially, their spread was facilitated by its accounting treatment expected by the APB Opinion No. 25. The replacement of the policy of the intrinsic value method to the fair value happened thanks to the option pricing models, including the Black and Scholes one in 1973 and the "binomial model" developed by Cox, Ross, and Rubinstein (1979).

${ }^{9}$ For an in-depth analysis on the main changes proposed by the exposure draft, see Bell et al. (2002).

10 The FASB on this occasion has adjusted to IFRS, specifically to IFRS 2, “Accounting for Share-Based Payments", issued by the International Accounting Standards Board (IASB) in February 2004. The change of the US principles in 2004 is one of the rare cases in which the FASB follows in the footsteps of the IASB. Regarding the accounting harmonization process, see the studies of Delogu (2006).
} 
The option pricing model of Black and Scholes (1973) differs profoundly from the intrinsic value method. ${ }^{11}$ The model is in fact based on a differential equation whose solution identifies the total value of the option. According to Black and Scholes (1973), the value of an option is the difference between the current price of the underlying asset, discounted at a rate equal to the expected dividends, and the exercise price, discounted at a rate equal to the return on investment without risk. Both the variables are multiplied by the probability that the stock price, at maturity, is higher than the exercise price of the option. ${ }^{12}$

The determinants of the value of an option are therefore the following:

(1) The expiry date of the option;

(2) The exercise price;

(3) The current value of the underlying asset;

(4) The expected dividend rate of the underlying asset;

(5) The expected volatility of the underlying stock;

(6) The rate of return on risk-free assets with a term equivalent to that option.

Despite its considerable complexity, the model has maintained so far a general recognition in the international markets and has been indicated by the FASB as a methodology suited to the evaluation process of the stock options. Furthermore, FASB Statement No. 123 established that the measurement of the cost depending on the configuration of the fair value must be made at the time of the plan and the cost should be allocated, according to the principle of competence, in the "service period"13. This period is meant to last from the issue date of the plan, so-called grant date ${ }^{14}$, the maturity date of the benefit, so-called vesting date, that is, when the right is exercisable by the employee. The cost is to be adjusted each year of service period, to take account of any changes in the number of options which are expected to reach maturity based on the occurrence or not of the conditions contained in the plan. If there are not the necessary elements for the measurement of cost the date of issuance of the options, that issuance time is delayed to the date on which the number of shares underlying the plan and the strike price of the options are known. As long as these elements are not known, it will register the cost on the basis of the intrinsic value, which is estimated on the assumption that the option is exercised immediately. The FASB believes that the cost should not be capitalized and therefore recognized as assets in the balance sheet and either entered as a negative in equity at the grant date. It is therefore suggested to recognize the cost for the compensation only when it is actually incurred, that is, during the service period, when the company uses the services provided by employees.

\section{The Evolution of Legislation in the European Context}

In Europe, the standard is represented by the IFRS 2, “Accounting for Share-Based Payments”, which specifically governs the accounting of the so-called share-based payment transactions. Before the IFRS 2, the principles of accounting for stock compensation were governed by the IAS No. 19, issued in 1998 by the International Accounting Standards Committee (IASC), predecessor of the IASB, which did not provide clear

\footnotetext{
11 The option pricing model, which is the algorithm for the evaluation of the options presented by Black and Scholes (1973), highlighted all the limits of the intrinsic value method for ending questioning the intrinsic value method in just one year from the issue of APB Opinion No. 25.

${ }^{12}$ For an in-depth analysis, see Bertoni (2005).

13 In US procedures, the service period is usually between 3 and 10 years. See on this Bertoni (2005).

14 The date on which the options are granted. If the grantee leaves, the company during the period of service is forced to abandon (forfeiting) the options (Hull, 2006). The assignee, in fact, may exercise the option only from the c.d. "vesting date" until the so-called maturity date, or the date of expiration of the option.
} 
provisions on the recognition of the cost of stock options, since there has not still been an international method of reference in terms of evaluation criteria. The IFRS 2 requires that all share-based remunerations (including costs related to stock options) be recognized as an expense in the financial statements (Bertoni, 2005), in order to ensure transparent and comparable information to users of financial statements. ${ }^{15}$ The international accounting standard requires firms, which provide the assignment of shares to employees or managers under the stock option plans, to assess those goods and services at fair value; according then to the mode of settlement of the transaction, will have noted an increase in equity if the goods or services are received on the basis of a transaction with share-based payments regulated with equity instruments (equity-settled) or a liability if the goods or services were acquired on the basis of a transaction with share-based payments settled in cash (cash-settled). The IASB proposes, in short, to account the fair value of options in the personnel costs, in order to offset the capital increase generated and to share it during the service period, to reflect the cost that the company supports over all the periods affected by the plan. In case it is not possible to obtain reliable estimates of fair value, the company must measure the value of goods and services received and the corresponding increase in net asset value, indirectly, referring to the fair value of the equity instruments granted. In particular, the fair value of those equity instruments must be measured at the grant date of the same (Iannucci \& Peroni, 2010). The logic underlying this finding lies in recognizing that, in fact, the beneficiary of the options is regularly working; for this reason, it can be considered the payment of a service in exchange for stock options of the company (Catuogno \& Peta, 2008). As regards the recognition of the cost in the budget, it is expected that this should be done at the time when the goods or services are consumed (Miele \& Russo, 2011).

In a stock option plan, the granting of equity instruments may be subject to meet certain conditions. Some types of "vesting condition"16 can be represented by constant maintenance of the employment relationship with the company for a defined period of time (the so-called service conditions) or by the achievement of management targets (the so-called “performance conditions”) (Quagli, 2013).

Consequently, no amount will be taken as consideration of goods or received services if the assigned equity instruments do not accrue because not reaching the previously planned "vesting condition" targets (Catuogno \& Peta, 2008).

Regarding the condition that may be fixed in a stock option plan, the IASB intervened in January 2008 with the modification of the IFRS 2 by providing further conditions that are not related to the vesting period of a stock option plan but other variables, the so-called non-vesting condition (Marraffa, 2009).

The modification of the IFRS 2 provides types of non-vesting conditions that cannot be influenced by either the company or the provider of work (for example, in the case where a condition is linked to a particular market index) and types of non-vesting conditions that can be influenced exclusively by the company or the service provider. In the first case, the failure to achieve the condition has no accounting reflection, while in the second one, it is appropriate that the company detects immediately at the income statement the remaining part (not yet charged) of the plan cost (Marraffa, 2009).

In light of what we have shown up to this point, it can be seen as the basic approach of the document required by the IASB which is the same as that indicated by the FASB statement No. 123: Fair Value of the Instruments, appointed at the grant date, with the recognition of the cost over the vesting period.

\footnotetext{
15 The IASB considers worthwhile that the cost of the options granted appears in the income statement. The absence of such an indication distorts strongly the company's performance and is completely at odds with the concept of comprehensive income (Bertoni, 2005).

${ }^{16}$ C.d. "vesting conditions" are realized in certain accruing conditions in order to grant options.
} 


\section{The Assessment and Accounting Treatment of Stock Options in Italy}

In Italy, the accounting and disclosures in the financial statements of the stock option plans in the past was very partial and essentially left to the will of the budget editor. The CONSOB communication No. 11508 of February 15, 2000, on the "Recommendations on the Information Regarding Stock Option Plans", now repealed, was merely recommending the appraised companies to include report on managing directors, detailed information "in order to provide comprehensive information on stock options data and to highlight the evolution over time of the plans" (Avallone \& Ramassa, 2006). However, nothing stated about the methodology to calculate the cost. ${ }^{17}$ Actually, until the issuing of the IFRS 2, the Italian legislation on the accounting of stock option plans resulted nonexistent (Collu, Foddis, Masala, \& Micocci, 2005).

Without a specific legislation on the matter, it was developed the practice of non-accounting stock options in company costs, with the result of omitting this information in the financial statements. The only reference was the civil law that merely regulates the issuance of shares to employees but not as manager incentives in the form of stock options. ${ }^{18}$ What the institutions concerned are the extraordinary assignment of profits to employees by granting free shares under Art. 2349 ("Actions and Financial Instruments in Favor of Employees") and the subscription by the workers of the newly issued shares resulting from an increase of share capital payment, subject to the limitation of shareholder subscription right under Art. 2441 (Sergiacomo, 2010). In the company accounting the recognition of equity plans as in the abovementioned circumstances does not provide the recognition of costs borne by the firm. When the company had the employees sign for shares, it had no obligation to account the issuance of the stock option plan. Therefore, the assignment of the right had no impact on either the income statement or the shareholders equity, but simply, it gave rise to a record in memorandum accounts as a commitment taken by the company to the beneficiaries. ${ }^{19}$ This will confer to certain employees additional pay such operation would produce no effect on the outcome of business management, referring to a disclosure voluntarily reporting such information to stakeholders (Avallone \& Ramassa, 2006). ${ }^{20}$ At year-end, it was then verified the existence of a negative difference between the exercise price of the options, the carrying value of the shares to be assigned, and eventually they proceeded to record a provision for risks and charges amounting to that difference. When exercising the options, in case of shares allocated free of charge, the operation originated a passive non-existence, charged to income, equal to the value of the securities, while in the presence of shares, granted as a payment, the transaction generated a profit or loss depending on the equivalent from the value of the treasury shares. The stock option statement was modified with the EU Recommendation 2004/913/EC on transparency of shareholders remuneration of managers (Melis et al., 2010) that brought the issue of Art. 114-bis by TUF "information to the market regarding the allocation of financial instruments to corporate officers, employees or collaborators”. ${ }^{21}$

\footnotetext{
${ }^{17}$ Actually, the information was disclosed to CONSOB, but it was not disclosed to the public by the latter (Di Pietra \& Riccaboni, 2001).

18 The accounting Italian principles still do not regulate the accounting treatment of stock options granted to employees. For an in-depth analysis, see Cerri and Sottoriva (2010).

19 This approach is based on the assumption that staff does not yield any additional utility, capable of remuneration, the production staged during the year, fueling the belief that the options granted constitute a kind of generosity that does not burden on the company. Therefore, neither the income for the year nor the working capital is distorted by the present case (Corbella, 2004).

${ }^{20}$ We talk about voluntary disclosure since the CONSOB communication No. 11508 of February 15, 2000 is only a recommendation for Italian companies.

21 The Article 114-bis, introduced by Law No. 262 of December 28, 2005 (Provisions for the Protection of Savings and Regulation of Financial Markets) and subsequently amended by Legislative Decree No. 303 of December 29, 2006 discipline: "the information that issuers whose securities are listed or widely distributed among the public that should provide the market during the award of compensation plans based on financial instruments to officers, employees and consultants of the company and its parent group” (see document Consultation of February 23, 2007 issued by CONSOB).
} 
This article provides that prior to the approval of the incentive plan, the issuer makes available to the public a report containing information about the features of the plan. Delegated by the legislator, the CONSOB subsequently regulated the "information on the allocation of financial instruments to corporate officers, employees, or collaborators ${ }^{\text {,22 }}$ disposing, through the new regulation ${ }^{23}$, that issuers of financial instruments, registered in Italy, will make available to the public a document containing such information: a description of the recipients in a specific form ${ }^{24}$; essential elements relating to the characteristics of the securities on which the compensation plans are based; a brief description of the motivating plans' reasons. In our country, the accounting framework for the issuance of stock option plans has changed with the introduction of international accounting standards. In view of the IFRS 2 accounting standard content of the IASB, firms who are required to use the international accounting standards (IAS adopter) are also required to detect the estimated cost associated with the issuance of stock options, measured by the fair value of granted options.

Furthermore, since the issue of international accounting standards also the firms that do not adopt IAS may apply the provisions of IFRS 2 when not in conflict with the rules of positive law and in the absence of other national indications of accounting practice (Cerri \& Sottoriva, 2010). ${ }^{25}$

The issuance of a stock option plan, according to the new guidelines, then generates a cost to be recognized in the income statement as staff remuneration and the cost is recognized during the period in which the beneficiaries provide their work to accrue the right to exercise the options themselves.

The accounting records are similar to those provided by the SFAS No. 123. The IFRS 2 provides for the charge of a financial cost regardless the nature of the transaction, crediting in return for an equity-settled transaction $^{26}$ account of equity or debt for cash-settled transactions ${ }^{27}$. Regarding the quantification of the option value, granted to be budgeted for cash-settled transactions, it will be necessary to use the criterion of fair value of the related debt, initially considering only the value of goods/services acquired and then the change of that value in relation to the conditions provided; for equity-settled transactions, instead, there is the fair value of the goods/services received; if that amount can be reliably estimated, or else must be made through an indirect estimate of the fair value of equity instruments granted. At this point, it seems important to emphasize that the IFRS 2 introduces a "presumption that discriminates the reliability of the estimate in relation of performance and the nature of the entity that is the counterparty in the transaction" (Avallone \& Ramassa, 2006, p. 780). In other words, the standard requires that in the presence of a rendered service by an employee, the value of that service cannot be properly assessed, since it is difficult to isolate the part of rendered service as consideration for equity instruments from that made in respect of the remaining remuneration types. Given these circumstances, the standard assumes that estimates of the value of the service are unreliable and therefore require a valuation at fair value of equity instruments to be made at the date of the

22 Resolution 15915 of May 3, 2007 which amended the regulation on issuers with the insertion of Article 84-bis.

23 Article 84-bis (Resolution 11971 of May 14, 1999 as updated by resolution No. 18210 of May 9, 2012).

${ }^{24}$ It is required to be indicated the following: the names of beneficiaries who are members of the board of directors or the management board of the issuer's securities, the controlling companies of the issuer and of the companies, directly or indirectly controlled, along with the categories of employees or consultants of the issuer and of the companies controlling or controlled by the issuer.

${ }^{25}$ Actually, most of Italian not IAS adopter companies follow an accounting treatment that differs from the provisions of IFRS 2. For further details, see Corbella and Florio (2010).

${ }^{26}$ Settled transactions are those that involve the sale of equity instruments, intended as shares or options on shares of the company upon receipt of goods or services performed by an employee or any other person (Iannucci \& Peroni, 2010).

${ }^{27}$ Cash-settled transactions are those which consist on the purchase of goods or services where the amount of its debt to the supplier is bound to the value of certain equity instruments of the company and that are settled in cash (Iannucci \& Peroni, 2010). 
shares. Instead, when the service is provided by a subject non-comparable to an employee, it is assumed the reliability of the estimate of the service received and it is required the direct assessment to be made on the date on which the service is rendered.

As regards the period over which the value of share options has to be spread, according to IFRS 2, in the absence of the vesting period, it is assumed that the service is provided in a single moment, which implies the recognition of the entire value at grant date actions. ${ }^{28}$ In the presence of the vesting period, it is assumed that the service is rendered continuously along this period, which requires the allocation of the total value of the service on the basis of competence.

The accounting treatment of stock option plans described above shows that the determination of fair value at grant date is essential for proper economic and financial communication, as it is this value that contributes to the formation of income in the years in which the service is obtained and consumed, in line with the principle of competence (Ciampaglia, 2008).

\section{The Effects of Accounting for Stock Options on Economic and Financial Communication}

The aim of this work is to deal, in an evolutionary point of view, reflexes of the accounting treatment of stock option plans on the financial statements and thus on the firms' economic and financial communication. The analysis conducted highlighted the delay of our country in the standardization and regulation of a tool that produces effects on business communication and hence on the choices of the markets. Prior to the introduction of international accounting standards, the only reference in the field was the civil law regarding the issue of shares and in terms of financial statements. The absence of a specific legislation has left to the discretion of the directors the accounting record of the stock options. The choice of accounting or not the cost of the stock options has important repercussions on business performance, with particular reference to the operating results and the balance indexes (Lanzavecchia, 2001). As seen, the companies which are required to adopt IFRS or exercise their right to adopt them recognize the costs associated with staff remuneration through stock options, while those who are not required to adopt IFRS do not report these costs in their budgets. Such companies reported (in equal conditions) better economic results than those that apply the IFRS. Therefore, the Italian system of accounting and the IFRS with respect to this aspect generates a dichotomy with important consequences. The performance indexes such as return on asset (ROA), return on sales (ROS), ROE, and data determined according to documents of income as earnings before interest and taxes (EBIT), earnings before interest, taxes, depreciation, and amortization (EBITDA), economic value added (EVA), generally used to assess performance levels in companies that do not apply the IFRS are lower, as well as are the denominators of the indices used to apply multiple methods of negotiation, such as EV/EBIT, EV/EBITDA (Corbella \& Florio, 2010).

Significant effects are also produced on the evaluation of the economic capital of the company (Bodie, Kaplan, \& Merton, 2003). A company that does not recognize the costs related to stock option plans has increased profits budgets, which are made up of value already spent to remunerate the management and no longer available to shareholders (Tagliavini, 2000).

\footnotetext{
${ }^{28}$ This approach stems from the fact that the remuneration of the employees in the form of financial instruments is provided in respect of professional services already made by employees during the given year. Therefore, it is assumed that employees have already provided the professional services to the company during the year and in the face of these receive as compensation, stock options (Ciampaglia, 2008).
} 
It is so distorted not only the current information given to the market but it is also affected the prospective assessment regarding the company made by financial analysts when evaluating the future income capacity of the enterprise. Essentially, the adoption of stock option plans for compensation reduces the accounting evidence in staff costs with consequences on the extent of the income period estimates. Hence, the importance of a proper and transparent use of such instruments as the information is essential in mature financial markets (Amato, 2002). A stock option plan also affects the distribution policy of dividends. According to the studies of Lambert, Lanen, and Larcker (1989), the issue of stock options pushes management to distribute dividends lower than they would distribute in the absence of stock options, as other equal conditions, the payment of a dividend reduces the value of the option. The interest of management is therefore to reduce the dividend to increase the expected value of their options. All this produces distortion of information given to the markets, as it affects the information on the earning capacity of the enterprise. In conclusion with regard to stock options (and not only to those), the situation in Italy is characterized, in fact, unlike the US, to a condition of "accounting dualism" (Corbella \& Florio, 2010), due to the coexistence of national accounting standards (Italian Generally Accepted Accounting Principles (GAAP)) and international accounting standards IAS/IFRS.

As stated, in fact, by Corbella and Florio (2010), since 2005 in European countries such as Italy, Germany, France, Greece, Portugal, Spain, and England, there are two different accounting systems: the national one and the IFRS, which provide different descriptions of the stock options, with significant effects on the measurements of the profit at year-end. Even under the same conditions of space and time, the two authors point out how the two accounting systems lead to different figures and different compositions of assets, liabilities, and operating results of the company (Corbella, 2004).

There are no valid reasons justifying such a difference in regulatory accounting in Italy with regard to stock option and this causes significant negative consequences in terms of universality and comparability of financial statements. The financial statements prepared by companies applying IFRS 2 are, in fact, comparable with those of other European companies listed on the stock exchange but are not comparable with those of the Italian ones following national accounting standards. The financial statements of the latter are comparable within the same group (Corbella \& Florio, 2010).

These differences in accounting treatment of stock options are in conflict with the need to universalize, compare, and make reliable budgets and lead to a double-level system (Corbella \& Florio, 2010). We can conclude, then, that with regard to stock options, the existence of these different rules and this dualism accounting creates significant problems regarding the comparability of financial statements and about the true and fair view of the business reality that can and must be inferred from the information of an economic and financial budget. ${ }^{29}$

\section{References}

Achard, P. O., \& Castello, V. (2000). Partecipazione finanziaria e incentivazione del management. I piani di stock option. Franco Angeli (Ed.).

Amato, P. (2002). I piani di stock options: profili sostanziali e procedurali tra prassi e diritto. Università Commerciale “L. Bocconi” di Milano, XVII Corso di Perfezionamento per Giuristi d’Impresa.

Apostolou, N. G., \& Crumbley, D. L. (2001). Accounting for stock options: The controversy continues. The CPA Journal, 71(5), 34-38.

${ }^{29}$ For an in-depth analysis, see Cordazzo (2009). 
Avallone, F., \& Ramassa, P. (2006). Alcune problematiche applicative dell’IFRS 2 alla luce della diffusione in Italia dei piani di stock option. Rivista dei Dottori Commercialisti, 57(4), 769-811.

Barlev, B., \& Haddad, J. R. (2003). Fair value accounting and the management of the firm. Critical Perspectives on Accounting, 14(4), 383-415.

Bell, T. B., Landsman, W. R., Miller, B. L., \& Yeh, S. (2002). The valuation implications of employee stock option accounting for profitable computer software firms. The Accounting Review, 77(4), 971-996.

Bertoni, M. (2005). Pagamenti basati su azioni: Contabilizzazione delle stock option e IFRS 2. Contabilità Finanza e Controllo, 10, 797-805.

Black, F., \& Scholes, M. (1973). The pricing of options and corporate liabilities. Journal of Political Economy, 81(3), 637-654.

Bodie, Z., Kaplan, R. S., \& Merton, R. C. (2003). For the last time: Stock options are an expense. Harvard Business Review, 81(3), 63-71.

Cappiello, S. (2003). Stock options e corporate governance. Analisi Giuridica dell'Economia, 1, 135-145.

Catuogno, S., \& Peta, M. (2008). La transizione all’IFRS 2 per le stock option. Gli effetti economici sull’informazione di bilancio. Quaderno Monografico Rirea, 69, 1-63.

Cerri, A., \& Sottoriva, C. (2010). I piani di compensi basati su strumenti finanziari: Profili giuridici, informativa esterna, problematiche di rappresentazione in bilancio e attività di vigilanza e di revisione legale dei conti. Il controllo nelle società $e$ negli enti, 3, 315-409.

Ciampaglia, G. M. (2008). I piani di stock options nelle società quotate in borsa in Italia: Il trattamento contabile secondo l'IFRS 2. Economia e diritto del Terziario, 1(1), 179-202.

Collu, M., Foddis, I., Masala, G. B., \& Micocci, M. (2005). La valutazione e la contabilizzazione delle stock option in base al principio contabile internazionale IFRS 2. Annali della Facoltà di Economia di Cagliari, Vol. XXII.

Corbella, S., \& Florio, C. (2010). Issues arising for accounting harmonization: The case of stock options in Italy. Accounting Forum, 34(3-4), 184-195.

Corbella, S. (2004). I piani di stock grant e stock option destinati al personale. Profili di misurazione del reddito di esercizio. Franco Angeli (Ed.).

Cordazzo, M. (2009). Principi contabili internazionali e risultati economici delle quotate italiane. Franco Angeli.

Cox, J. C., Ross, S. A., \& Rubinstein, M. (1979). Option pricing: A simplified approach. Journal of Financial Economics, 7(3), 229-263.

Dechow, P. M., Hutton, A. P., \& Sloan, R. G. (1996). Economic consequences of accounting for stock-based compensation. Journal of Accounting Research, 34, 1-20.

Delogu, A. (2006). I principi contabili internazionali IAS 2005. Retrieved from http://www.archiviogiuridico.it/

Di Carlo, F. (2009). Le stock option nell'economia dell’impresa. Giappichelli Editore.

Di Pietra, R., \& Riccaboni, A. (2001). Le stock option in Italia: Caratteri generali, profili fiscali ed obblighi di informativa societaria. In K. Merchant, \& A. Riccaboni (Eds.), Il controllo di gestione. McGraw-Hill.

Filonzi, L. (1999). I piani di stock option: I riflessi sulla contabilità e sull'informativa di bilancio. Analisi finanziaria, n. 34.

Freeman, G. R., \& Larsen, G. A. (1997). The market’s reaction to the FASB stock-based compensation project. Journal of Applied Business Research, 13(4), 83-91.

Guay, W., Kothari, S. P., \& Sloan, R. (2003). Accounting for employee stock option. American Economic Review, 93(2), 405-409.

Hull, J. C. (2006). Options, futures, and other derivates (6th ed.). Pearson Paravia Bruno Mondadori.

Iannucci, A., \& Peroni, C. (2010). IFRS 2: Pagamenti basati su azioni. Documento della Commissione Imposte Dirette, Reddito d'Impresa e Operazioni straordinarie dell'Ordine dei Commercialisti di Roma.

Jensen, M. C., \& Meckling, W. H. (1976). Theory of the firm: Managerial behavior, agency costs, and ownership structure. Journal of Financial Economics, 3(4), 305-360.

Lambert, R. A., Lanen, W. N., \& Larcker, D. F. (1989). Executive stock option plans and corporate dividend policy. The Journal of Financial and Quantitative Analysis, 24(4), 409-425.

Lanzavecchia, A. (2001). Stock option e valore d'impresa, gli interessi degli azionisti sono da tutelare. Amministrazione \& Finanza, n. 8/2001.

Marraffa, V. (2009). L'azionariato dei dipendenti come forma di incentivazione: Ascesa e declino delle stock option? La nascita, lo sviluppo e la situazione attuale dal punto di vista economico, societario, contabile, fiscale e previdenziale. I Quaderni della Scuola di Alta Formazione, n. 22.

Melis, A., Carta, S., \& Gaia, S. (2011). I compensi basati su azioni. Principi, teorie ed evidenze empiriche. Giuffrè Editore. 
Miele, L., \& Russo, V. (2011). Deducibile il costo delle “stock option” per i soggetti “IAS adopter”. Corriere Tributario, 34(27), 2187-2192.

Onesti, T., \& Romano, M. (2010). Le politiche di remunerazione degli amministratori esecutivi e dei dirigenti con «responsabilità strategiche». In F. Fortuna (Ed.), La corporate governance nell'esperienza nazionale e internazionale: Aspetti comparativi e profili evolutivi. Ed. Il Mulino.

Quagli, A. (2013). Bilancio di esercizio e principi contabili. Giappichelli Editore.

Sergiacomo, A. (2010). Stock option: Aspetti contabili e normative. Guida alla Contabilità \& Bilancio, n. 22.

Tagliavini, G. (2000). Il valore dell'azienda «sconta» il piano di stock option? Amministrazione \& Finanza, n. 20/2000.

Zattoni, A. (2001). I piani di stock option per il top management. In G. Airoldi, \& A. Zattoni (Eds.), Piani di stock option: Progettare la retribuzione del top management. Milano: Egea.

Zattoni, A. (2003). I piani di stock option in Italia: Diffusione e caratteristiche. Economia e Management, 6, 71-90. 